\title{
Effects of Land Use on the Soil Organic Carbon Storage Potentiality and Edaphic Factors in Tripura, Northeast India
}

\author{
Bal Krishan Choudhary*, Koushik Majumdar, B. K. Datta \\ Department of Botany, Tripura University, Suryamaninagar, India \\ Email: "bkmchoudhary@gmail.com
}

Received 26 February 2016; accepted 11 September 2016; published 14 September 2016

Copyright (C) 2016 by authors and Scientific Research Publishing Inc.

This work is licensed under the Creative Commons Attribution International License (CC BY). http://creativecommons.org/licenses/by/4.0/

(c) (7) Open Access

\section{Abstract}

The regulatory functions of soil are getting attention among the scientists and Soil Organic Carbon (SOC) is an important indicator of soil health. The impact of differential use of land on SOC and other edaphic properties were analysed in three important Land use land cover (LULC) system of Tripura, northeast India. Soil cores were divided into four depth profiles $(0-10,10$ - 30, 30 - 50 and $50-100 \mathrm{~cm}$ ) to observe the changes of edaphic properties into the soil depth gradient. Our results suggest that SOC in the top profile of Managed Plantation (MP) and Jhum Fellow (JF) was $51.68 \%$ and $48.55 \%$, less than Natural Forest (NF). From 0 - 10 to 10 - $30 \mathrm{~cm}$ soil depth, $43.3 \%, 8.4 \%$ and $39.4 \%$ decrease in NF MP and JF found. Total stock of SOC (Mg C.ha-1) was found highest in JF (121.87), followed by NF (117.12) and MP (85.34). In top profile, conversion of NF into MP and NF into JF led to $39 \%$ and $11 \%$ decrease in SOC. The significant variation in SOC stock was found among different LULC under this study $\left(F_{2,12}=16.94, P \leq 0.001\right)$. In $0-10 \mathrm{~cm}$ soil depth, maximum value of bulk density $\left(\mathrm{gm} \cdot \mathrm{cm}^{-3}\right)$ was found in MP (1.39) followed by JF (1.27) and NF (1.23). In top profile, significant variation was found among LULC $(\mathrm{p}<0.001)$. Soil $\mathrm{pH}$ and moisture content significantly varied $(p<0.05)$ in $0-10,10-30$ and $50-100 \mathrm{~cm}$ soil depth. In contrast to that significant change in soil temperature was found at $30-50 \mathrm{~cm}(\mathrm{p}<0.001)$ and $50-100 \mathrm{~cm}(\mathrm{p}<0.001)$. It was observed that JF had highest overall SOC stock than NF and MP. Conversion of NF into MP and JF results significant loss of SOC at $0-10$ and $10-30 \mathrm{~cm}$ depth profile. We also found that NF conversion had significant impact on the change in the soil $\mathrm{C}$ pool.

\section{Keywords}

Land Use Land Cover, Soil Profile, Soil Organic Carbon, Edaphic Properties

\footnotetext{
${ }^{*}$ Corresponding author.

How to cite this paper: Choudhary, B.K., Majumdar, K. and Datta, B.K. (2016) Effects of Land Use on the Soil Organic Carbon Storage Potentiality and Edaphic Factors in Tripura, Northeast India. American Journal of Climate Change, 5, 417-429. http://dx.doi.org/10.4236/ajcc.2016.53031
} 


\section{Introduction}

The Land use land cover (LULC) is the common term to describe natural or manmade feature on earth, where land use describes how a piece of a land is managed or used by humans and land cover is the observed physical and biological cover of the land such as vegetation or man-made features [1]. To meet demand of food and timber, the growing population has drastically changed the land use pattern in tropical forests [2]. Over the last decade there has been increasing interest in the impact of differential LULC on tree diversity and other ecosystem properties. This rapidly accelerating change in the LULC is associated with a wide variety of issues, including declining biodiversity [3], global climate change and food security, and land degradation as it applies to soils, vegetation and water. Regulation function of tropical soil is receiving much interest by the scientific communities as it is an important part of the biosphere and has a higher potential to store carbon compared to vegetation and atmosphere [4]. Since, about $14 \%$ of the world soil carbon is located in the soils of tropical forests [5]. It has been estimated at approximately 3.3 times the size of the atmospheric pool and 4.5 times the size of the biotic pool [6] [7]. The soil Carbon (C) pool mainly comprises Soil Organic Carbon (SOC) estimated at $1550 \operatorname{Pg}\left(1\right.$ petagram $=10^{15} \mathrm{~g}=1$ billion ton) and Soil Inorganic Carbon (SIC) of approx. 750 Pg, occurred up to $1 \mathrm{~m}$ depth [8]. In fact, two-thirds of the carbon in terrestrial ecosystems comes from SOC [9]. It has been estimated that an increase in SOC by $0.01 \%$ could lead to the $C$ sequestration equivalent to annual increase of atmospheric Carbon-dioxide Carbon [10]. The land-use changes in the tropics are estimated to contribute about 23\% to human-induced $\mathrm{CO}_{2}$ emissions [11]. Rapid and unprecedented changes in land uses for increasing demand of food, water, energy and space to meet the demands of increasing population has drawn the keen interest of many ecologists [12]. Land use land cover (LULC) change causes perturbation of the ecosystem and can influence the C stocks and fluxes. Since the 19th century, around $60 \%$ of the $\mathrm{C}$ in the world's soils and vegetation has been lost owing to land use change [13].

The conversion of land use from forest to plantation or agriculture leads to emission of carbon due to biomass loss [14]. Further, out of total C stored in an ecosystem, $89 \%$ loses are due to loss of living biomass and it is one of the important indicators of ecosystem services [14]. An accurate estimation of SOC and the effects of LULC on $\mathrm{C}$ balance in the ecosystem are important to global climate change studies and to terrestrial carbon cycle research [15]. Estimation of SOC stock in forest soil is important as approximately $70 \%$ of the C stored within the forest ecosystem is stored within forest soil [16] [17]. According to IPCC [5] the major cause for the increase in C in the atmosphere ( $90 \%$ of net release) is change in LULC in the tropics. The magnitude of decline in soil C depends on the soil depth used for $\mathrm{C}$ estimations and time scale for land use change [5]. For example, agriculture, through conversion of forests and grassland during past 140 years, has led to a net release of about $121 \mathrm{Gt} \mathrm{C}$, of which about $60 \%$ has been emitted in tropics and remaining $40 \%$ in middle and high latitudes [5]. The annual flux of C from LULC changes to the atmosphere was estimated at $2.2( \pm 0.6) \mathrm{Pg} \mathrm{C} / \mathrm{yr}$ in the 1990s [11]. C gains by rehabilitation of eroded and decertified soils have been estimated to be of the order of 0.1 to $0.4 \mathrm{t} \mathrm{C} / \mathrm{ha} / \mathrm{yr}$ [18].

In order to estimate the change in the $\mathrm{C}$ stocks of soils, it is first necessary to establish baseline data. The size of the stock of SOC at regional levels is essential information to understand the changes in C content and its fluxes. An accurate estimation of the effects of LULC on C balance in the ecosystem is important to global climate change studies and to terrestrial $\mathrm{C}$ cycle research. As $\mathrm{C}$ stock estimation greatly help scientists to monitor and predict ecosystem response as well as aiding policymakers, when they will take land use change and management decisions and assisting land managers to gain better access to C markets [19]. To assess the effect of LULC, we focused our investigation mainly on the SOC in different soil horizons, which are generally less responsive to disturbances [20]. However, SOC is one of the most important indicators of soil fertility, productivity, quality and decline in SOC adversely affects the land productivity [21]. In fact, for last few years one-quarter of the global land area has suffered significant decline in soil productivity and losses major portion of soil C stock which essential for several important ecosystem services [22]. Instead of soil contains a significant part of global carbon stock (3.5\%), very few studies have taken to quantify the $\mathrm{C}$ and its implication. Even, most of the $\mathrm{C}$ stock assessments were restricted to the above ground and estimation of below ground SOC remain poorly understood. Since, there is growing interest of in assessing the role of soil as $\mathrm{C}$ sink in different land use system including forest ecosystem. Thus, to understand the mechanisms and factors of SOC dynamics in different land use-systems are important to identifying and estimate $\mathrm{C}$ sequestration to mitigate the climate change effects. Current scientific knowledge of how local soil properties and climatic conditions affect soil C stock changes and C fluxes is insufficient and conflicting [23]. In tropical and subtropical regions, soil ecosystem is highly fragile 
and depleted of SOC, enhancement of organic carbon is very important [24]. The SOC loss is also influence by edaphic properties as soil respiration is influenced mainly by soil temperature and moisture. Hence, estimation and analysis of edaphic properties like soil $\mathrm{pH}$, bulk density, soil temperature and moisture content is also considered important. In background of the above information, the objectives of this study were: 1 ) to estimate the edaphic properties in some selected LULC systems in Tripura, Northeast India, and 2) to examine the effects of LULC on SOC stock potential and other edaphic properties. It was hypothise that the differential use of land has impact on SOC and edaphic properties.

\section{Materials and Methods}

\subsection{Study Area}

Tripura is the India's third smallest hilly state, located in the northeast part of the country. Tripura lies approximately between the latitudes $22^{\circ} 56^{\prime} \mathrm{N}$ and $24^{\circ} 32^{\prime} \mathrm{N}$ and between longitudes $91^{\circ} 0^{\prime} \mathrm{E}$ and $92^{\circ} 22^{\prime} \mathrm{E}$ in the north east extension ranges of Himalaya. It is bound on the North West, south and south-east by Bangladesh, where as in the east it has a common boundary with Assam and Mizoram states. It is the land of high hills, hillocks and patches of plains interspersed with rivers and valleys having moderately warm and humid climate. According to the census report 2010-2011 the total population of the state was 36.71 lakh. The indigenous tribal populations living in the hills have traditionally derived their livelihood from forest resources of the state. The present study was conducted in North, Unakoti and Dhalai Districts of Tripura (Figure 1). Three most abundant lands uses viz. Natural Forest (NF), 25 year old Shorea robusta-Managed Plantation (MP) and one year old Jhum Fellow (JF) were selected for the study.

\subsection{Climate}

The climate of the whole year of the state is mainly having four seasons. December to February is the cold season which is followed by summer season (March-May), June to September is the monsoon season and October to November is the post monsoon period. The cold weather starts by the end of November and continues to February with daily maximum temperature of $26^{\circ} \mathrm{C}$ and minimum $8^{\circ} \mathrm{C}-4^{\circ} \mathrm{C}$. During summer season (MarchMay), maximum temperature is $38^{\circ} \mathrm{C}$. Humidity remains high throughout the year and in summer season the relative humidity ranges $50 \%-75 \%$ while in monsoon period they are over $85 \%$. State receives an average of $247.9 \mathrm{~cm}$ rains within a year. About $63 \%$ of the annual rainfall is caused by the south-west monsoon. The mean wind speed is $7.1 \mathrm{~km} / \mathrm{hr}$, with maximum of $13.1 \mathrm{~km} / \mathrm{h}$ in May and minimum of $3 \mathrm{~km} / \mathrm{h}$ in December. The monthly annual average temperature; relative humidity and precipitation recorded at Indian meteorological station, Agartala is given in Figure 2. Due to maximum precipitation and high humidity Tripura is floristically very rich and covered with largely evergreen and moist deciduous forests. The geology of Tripura as a whole comprises of sedimentary rocks which have been grouped into the suma group (further Dupitilla group). The sedimentary group range in age from mid-tertiary ( 15 million years to recent $(<1$ million year old). The soil of the state is laterite in hills and hillocks and alluvial in plains and foot hills and very rich in iron oxides.

\subsection{Description of Land Use Land Covers (LULC)}

For the present study we selected three different land uses in Tripura. The forests in the state are mainly tropical semi evergreen and moist deciduous and cover $77.18 \%$ of total geographical area, where $4686 \mathrm{~km}^{2}$ area under moderately dense forests and $3182 \mathrm{~km}^{2}$ areas under open forest [25]. However, actual forest area is about $60.02 \%$ of its geographical area including Reserve Forest (66.33\%), Protected Forests (0.03\%) and Unclassed Forest (33.64\%) [25]. Since, NF is the most important land use land cover of the state, thus we select NF based on the visual characteristics (Figure 3(a)). MP are having different choices of commercial timber yielding species like Shorea robusta, Tectona grandis, Gmelina arborea, Syzygium sps., Hevea brasiliensis, Cassia sps., Lagestroemia sps., Shorea robusta, Dipterocarpus turbinatus and orchard like Lichi chinensis, Anacardium occidetalis etc. Here we selected Sal plantation in north Tripura, which managed by local forest Department (Figure 3(b)). According to State Forest Report, 2013, total areas under in plantation forest are 30,915 ha (1972), 55,485 ha (1978), 2, 25,078 ha (1998) and 2, 98,851 ha [26] respectively. Jhum cultivation is the major form of agroforestry practiced in the region. The entire socio-economic structure is woven around this system and farmers maintain high species diversity. Due to shortening the period, lack of labour force and changing the source of 


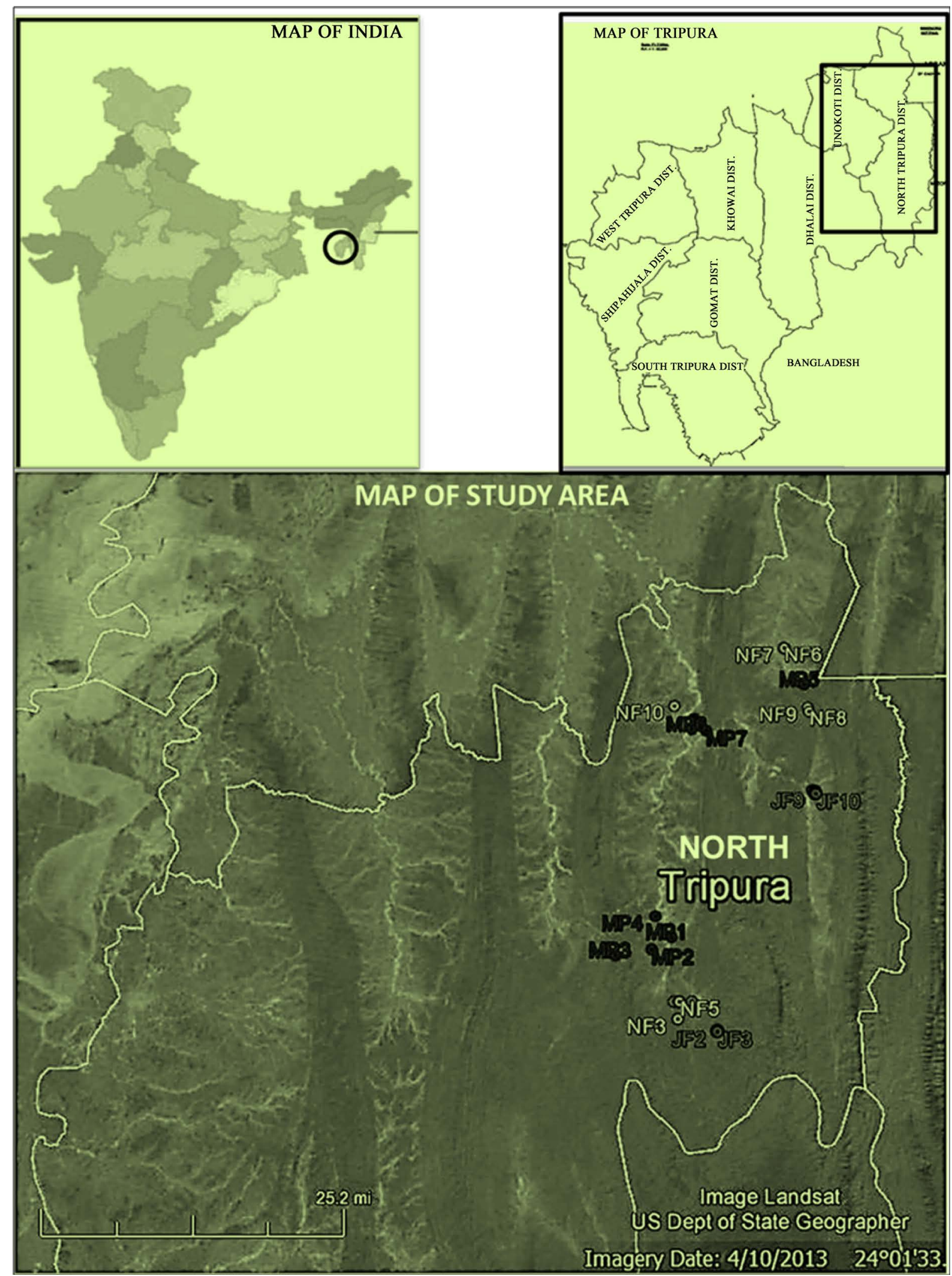

Figure 1. Map showing different locations of sampling in Tripura, Northeast India (NF-Natural Forest, MP-Manage Plantation and JF-Jhum Fallows). 


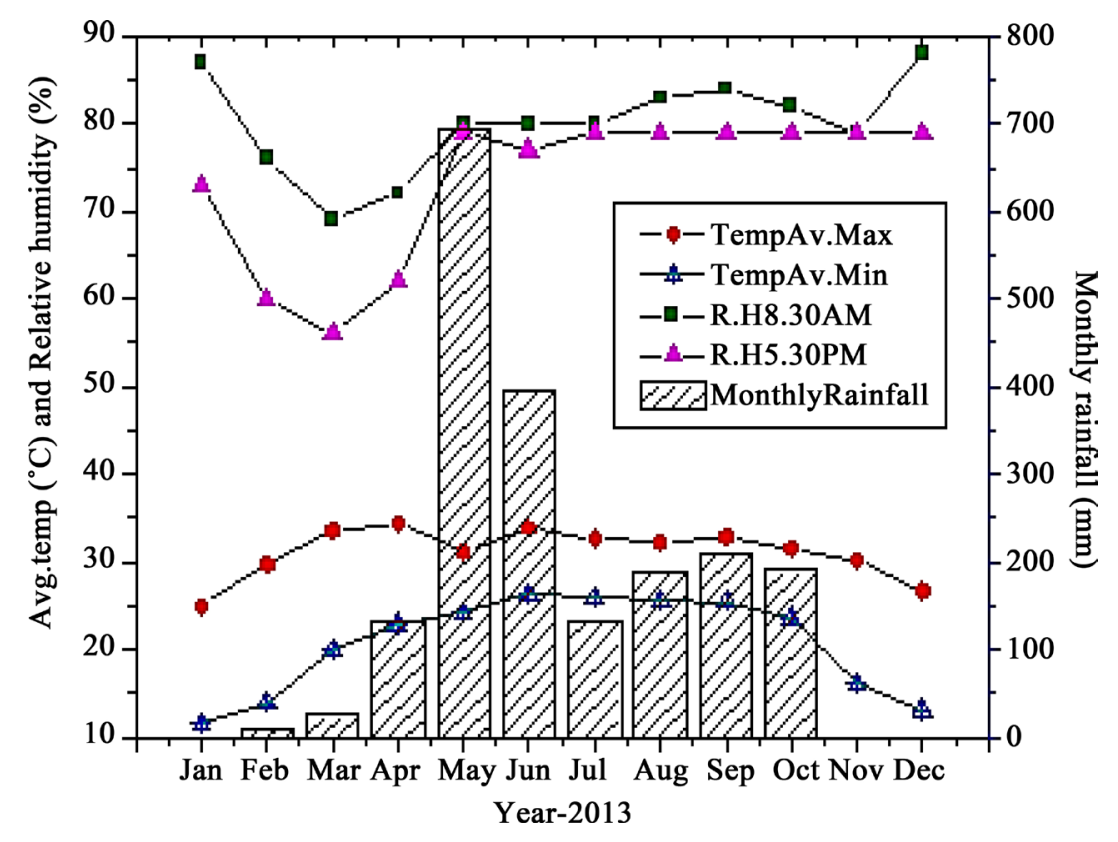

Figure 2. Showing the different meteorological parameters of the study area.

livelihood by tribal people various JF land are scattered all over the hills of state [27]. For the present study we selected Jhum land which was fallowed for last one year (Figure 3(c)). Under rehabilitation scheme till 2013 government has given total 169,292 ha of land to 120,418 No. of Jhumias families [26].

\subsection{Methods}

After completion of reconnaissance survey and selection of each land use, we adopted stratified random sampling method for the study. Soil sampling was done in March 2013. In three LULC, 30 permanent plots of $100 \times$ $10 \mathrm{~m}$ were fixed and five equal areas of $10 \times 10 \mathrm{~m}$ set for soil sampling. Out of 30 transects, 10 were laid in NF; 10 in MP and 10 in JF. The study of SOC contents of soil were done on unit area basis, for specific depth interval. Total, 30 composite samples were taken at the upper, middle and lower slope positions of each LULC type on the landscape. Soil cores were divided into four depth profiles of $0-10 \mathrm{~cm}, 10-30 \mathrm{~cm}, 30-50 \mathrm{~cm}$ and 50 $100 \mathrm{~cm}$. Soil was thoroughly mixed and the large fragments of plant materials, roots were removed by handsorting. Field-moist samples were gently crumbled manually and sieved to remove root material. Samples were homogenized and air-dried, ground and passed through $2 \mathrm{~mm}$ sieve and stored for analysis. Undisturbed soil core samples were used for field bulk density analysis. For each depth five replicates of each composite were analyzed. The SOC was estimated by wet oxidation method [28]. Dry soil bulk density $\left(\mathrm{g} \mathrm{cm}^{-3}\right)$ at $105^{\circ} \mathrm{C}$ was estimated by the core method [29]. The stock value on mega gram per hectare $\left(\mathrm{Mg} \mathrm{C} \mathrm{ha}^{-1}\right)$ basis was calculated by following standard method [20]. Soil pH was measured in $1 \mathrm{M} \mathrm{KCl}$ suspension of 1:5 (soil:liquid) using a pen type digital pH meter (Hanna-Hi96107). Soil moisture was calculated on dry weight basis [30] and soil temperature for each depth profile was measured using soil thermometer (Model 6310). The ANOVA and $t$-test were done to compare the means of structural variables, $\mathrm{C}$ pools and other edaphic properties in different LULC. Principal Component Analysis (PCA) based on some important edaphic factors was used to observe the changes along different depths in all land uses. All statistical analysis was performed by PAST version 1.89 [31].

\section{Results and Discussion}

\subsection{Effect of Land Use and Soil Depth on SOC Stock}

In all land uses SOC (\%) stock decreases from top to lower layers and maximum change was noticed, when we compared 0 - 10 with 10 - $30 \mathrm{~cm}$ soil depth i.e. SOC stock decreased by 60.5\%(NF), 68.03\%(MP) and 65.07\% (JF) (Figure 4). But in complete profile along three land uses, the \% of SOC was found to low in MP (26.31), 


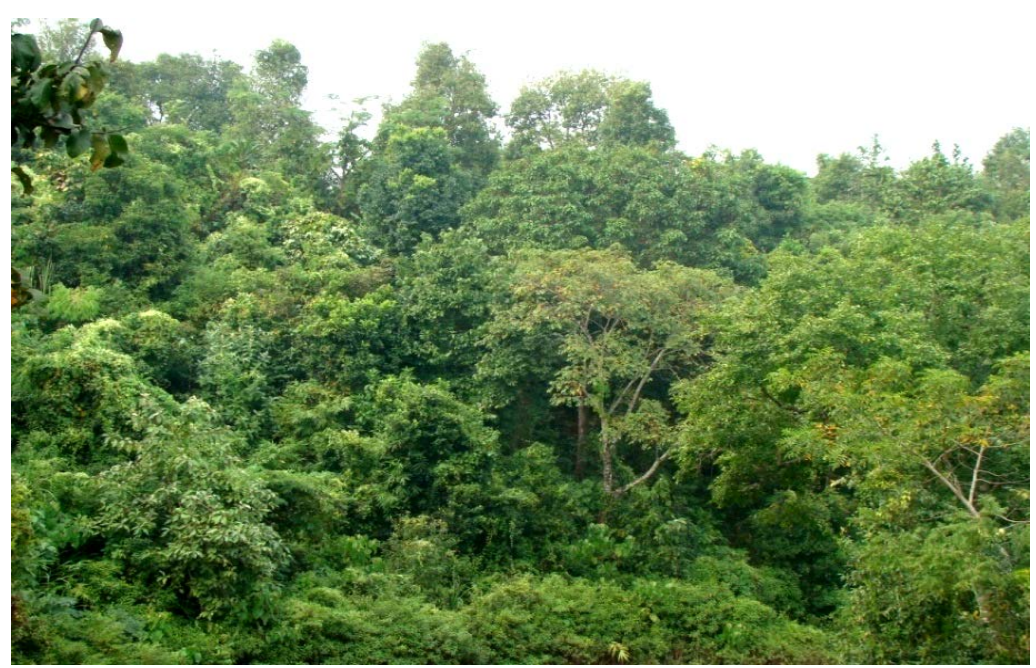

(a)

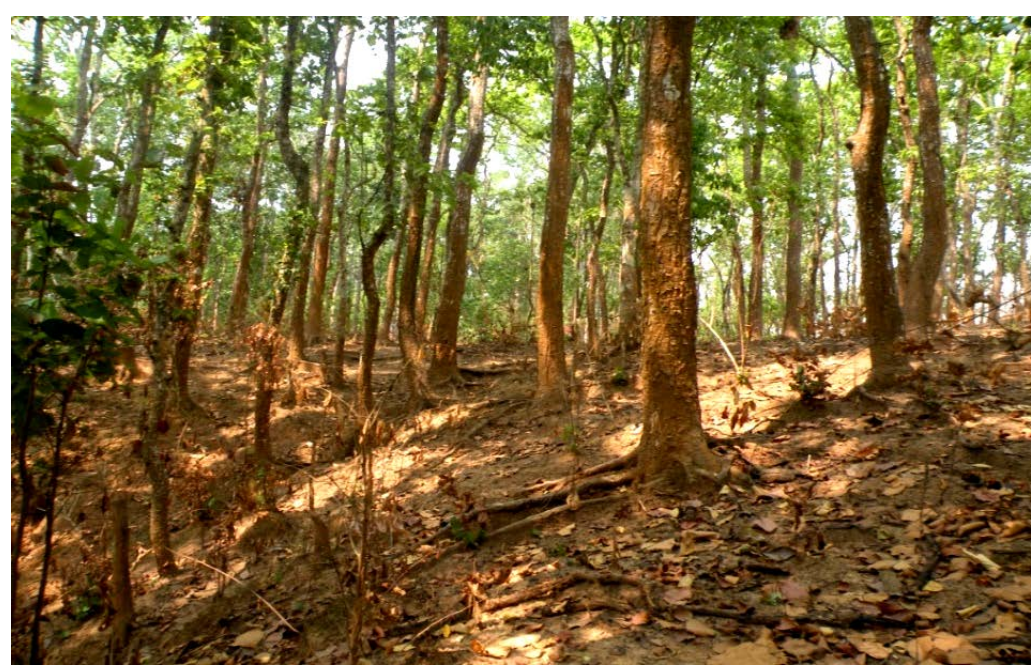

(b)

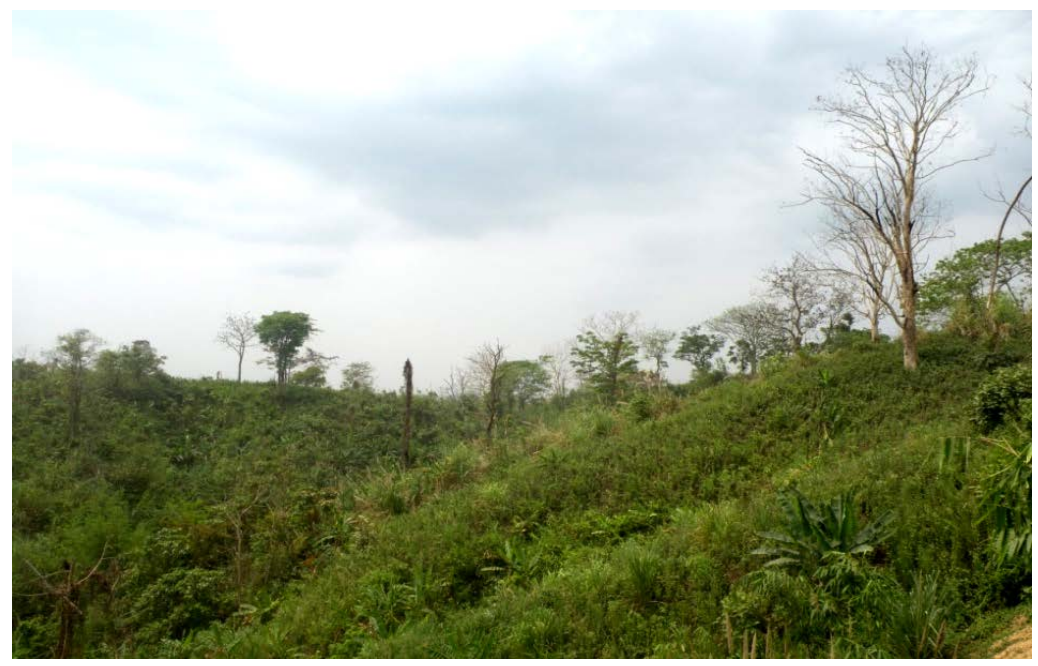

(c)

Figure 3. Three different land uses in Tripura, Northeast India ((a) NF-Natural Forest, (b) MP-Manage Plantation and (c) JF-Jhum Fallows). 


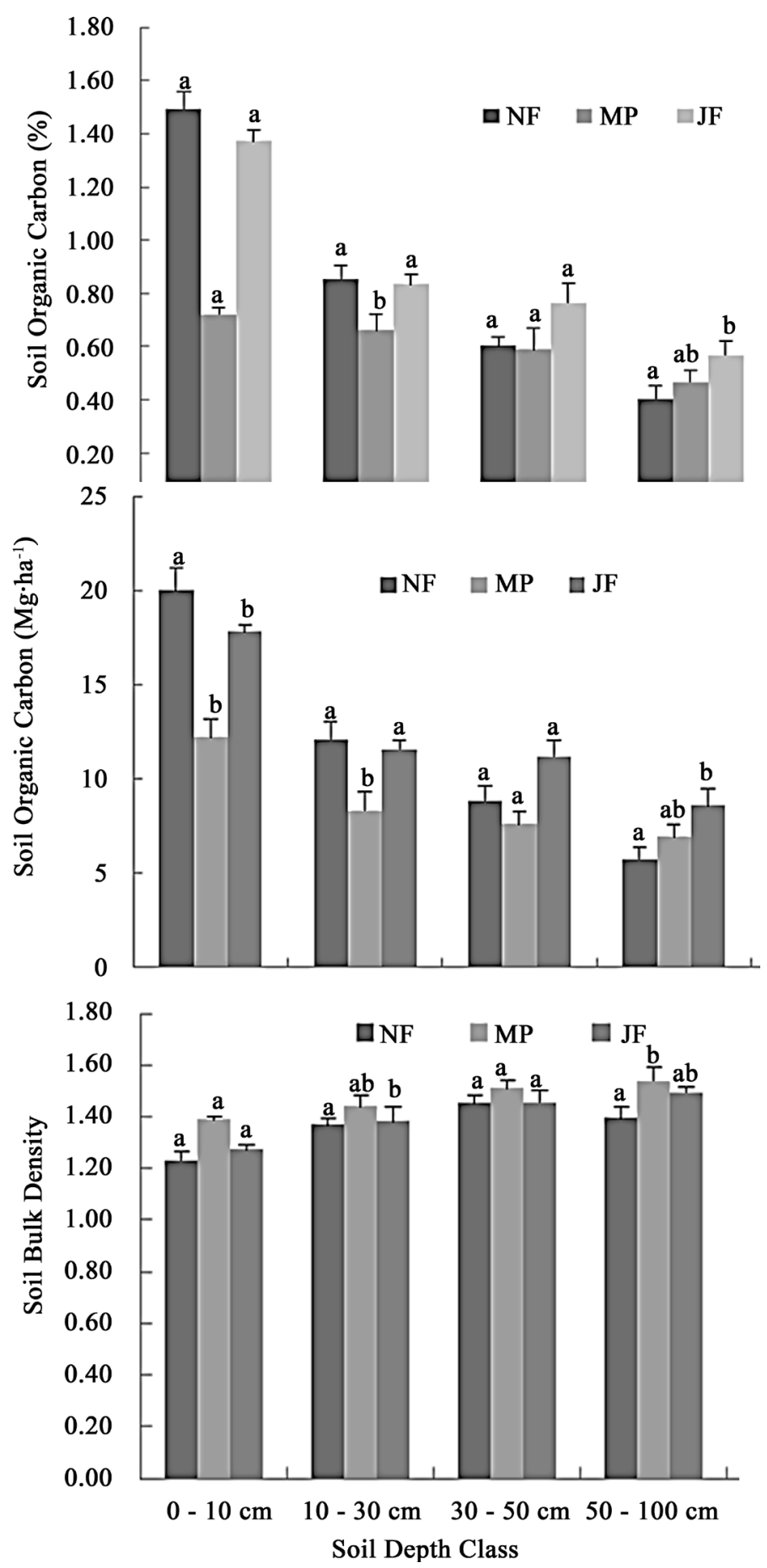

Figure 4. Value (Mean $\pm \mathrm{SE}$ ) of soil organic carbon (\%), organic carbon stock $\left(\mathrm{Mg} \cdot \mathrm{ha}^{-1}\right)$ and bulk density under three land use systems (NF-Natural Forest, MP-Manage Plantation and JF-Jhum Fallows) in Tripura, Northeast India. Means sharing the same letter are not statistically different (Tukey, $\mathrm{p}<0.05$ ).

NF (36.11) and in JF (37.57). In complete profile, SOC (\%) ranged from 0.88 (JF) to 0.61 (MP). In top profile, conversion of NF into MP led to 39\% decrease in SOC, where as conversion of NF into JF led to only $11 \%$ decrease in SOC. The maximum value of SOC stock $\left(\mathrm{Mg} \mathrm{C} \mathrm{ha}^{-1}\right)$ was found high in JF (121.87), followed by NF (117.12) and MP (85.34) (Table 1). In top profile i.e. 0 - $10 \mathrm{~cm}$ soil depth, maximum value of SOC stock was found in RF (20 \pm 2.73$)$, followed by JF $(17.81 \pm 2.22)$ and MP $(12.20 \pm 0.85)$ (Figure 4). There was significant 
variation in SOC stock was found among different land use land cover under the study $\left(\mathrm{F}_{2,12}=16.94, \mathrm{P} \leq 0.001\right)$. Similarly in $30-50 \mathrm{~cm}$ soil profile, SOC stock significantly varied $\left(\mathrm{F}_{2,12}=6.08, \mathrm{p} \leq 0.05\right)$, but in complete profile again stock did not varied significantly $\left(\mathrm{F}_{2,12}=61.79, \mathrm{p} \leq 0.05\right)$. When we compared the total value of stock of each depth class, we found that conversion of NF into MP led to $27.14 \%$ decrease in stock, where as conversion to NF into JF, led to increase in stock by 4\%. In top profile, percent value of SOC was highest for NF (1.49) followed by JF (1.37) and MP (0.72), where as in complete profile, maximum value was recorded for JF (0.87). The value of SOC significantly varied in $50-100 \mathrm{~cm}$ soil depth $\left(\mathrm{F}_{2,12}=4.51, \mathrm{p} \leq 0.05\right)$. In top profile again MP had 51.68 and $48.55 \%$ less SOC than NF and JF respectively. There was sudden decrease in \% SOC noticed, when we compared 0 - 10 to 10 - $30 \mathrm{~cm}$ soil depth i.e. $43.3 \%$ decrease in NF followed by $8.4 \%$ in MP and $39.4 \%$ in JF. So, NF showed maximum change, but in complete profile no significant change was noticed. In 50 - $100 \mathrm{~cm}$ soil depth profile, the percent of SOC followed an order of NF $<\mathrm{MP}<\mathrm{JF}$. Overall MP had 26.24 and 28.60\% less $C$ than NF and JF respectively. The value of bulk density ranged from 1.47 (MP) to 1.37 (NF) and found significantly high in $\mathrm{NF}\left(\mathrm{F}_{2,12}=5.27\right.$; $\left.\mathrm{p}<0.05\right)$. The value of bulk density increased with increase in depth in all LULC (Figure 4).

\subsection{Effect of Land Use and Depth on Edaphic Properties}

PCA generated eigen value of 284.18 with $99.07 \%$ variation for Axis-1 and 2.11 with $0.74 \%$ variation for Axis-2 (Figure 5). PCA suggested significant variation of soil edaphic factors in different depths of three LULC, where NF showing maximum moisture content almost in all depths. In fact, SOC and pH was high at the top layer of the soil in NF. But, soil temperature and $\mathrm{pH}$ was high bellow 0 - $10 \mathrm{~cm}$ soil depths in MP. In addition, surface soil temperature and SOC in second and third depths were high for JF. All soil samples analysed in the present study were strongly acidic. In case of complete soil profile, we recorded maximum $\mathrm{pH}$ value for JF (4.40 $\pm 0.17)$ than $\mathrm{NF}(4.39 \pm 0.18)$ and $\mathrm{MP}(4.40 \pm 0.17)$. In top profile overall soil $\mathrm{pH}$ significantly varied $\left(\mathrm{F}_{2,12}=\right.$ 4.46; $\mathrm{p}<0.05$ ) (Figure 6). In the $30-50 \mathrm{~cm}$ soil depth also $\mathrm{pH}$ significantly varied $\left(\mathrm{F}_{2,12}=10.21\right.$; $\left.\mathrm{p}<0.05\right)$, but in complete profile it did not showed any significant variation $\left(\mathrm{F}_{2,12}=0.01 ; \mathrm{p}<0.98\right)$. The value of $\mathrm{MC}(\%)$ was ranged between $18.82 \%(\mathrm{JF})$ and $15.79 \%(\mathrm{MP})$. Moisture content varied significantly when we compared individual profile i.e. 0 - $10 \mathrm{~cm}\left(\mathrm{~F}_{2,12}=4.46, \mathrm{p}<0.05\right)$ and $30-50 \mathrm{~cm}\left(\mathrm{~F}_{2,12}=14 ; \mathrm{p}<0.05\right)$ soil depth. Similarly in 50 - $100 \mathrm{~cm}$ depth, significant variation was also found in soil moisture $\left(\mathrm{F}_{2,12}=9.46 ; \mathrm{p}<0.05\right)$. The value of soil temperature $\left({ }^{\circ} \mathrm{C}\right)$ ranged from $26.68 \pm 1.01(\mathrm{JF})$ to $23.29 \pm 0.39(\mathrm{NF})$ and over all it differed significantly $\left(\mathrm{F}_{2,12}=\right.$ 27.63; p < 0.001). In 0 - 10 and 10 - $30 \mathrm{~cm}$ soil depth no significant change was found. But, in $30-50 \mathrm{~cm}\left(\mathrm{~F}_{2,12}\right.$ $=16.22 ; \mathrm{p}<0.001)$ and $50-100 \mathrm{~cm}\left(\mathrm{~F}_{2,12}=22.28\right.$ and $\left.\mathrm{p}<0.001\right)$ soil depth significant change in soil temperature. Soil moisture content increased with depth in NF and JF, but in MP did not show any definite trend. The value of soil temperature showed $\mathrm{MP}<\mathrm{NF}<\mathrm{JF}$ in $0-10 \mathrm{~cm}$ soil depth, but overall the trend was different i.e. NF $<$ MP $<$ JF. As per depth, soil temperature did not show any definite trend, but it increased from NF to MP and from MP to JF for all depth profile. In 0 - $10 \mathrm{~cm}$ soil depth maximum value of bulk density was found in MP

Table 1. Showing different edaphic properties (mean \pm standard error) along different land use land cover, Tripura, Northeast India. Variations are analyzed by ANOVA (degree of freedom 2, 13).

\begin{tabular}{|c|c|c|c|c|c|}
\hline Soil Parameter & NF & MP & JF & F-value & $p$-value \\
\hline Soil pH (KCL) & $4.39 \pm 0.18$ & $4.40 \pm 0.14$ & $4.40 \pm 0.17$ & 0.012 & 0.98 \\
\hline Moisture Content (\%) & $18.20 \pm 0.78$ & $15.79 \pm 0.91$ & $18.82 \pm 1.61$ & 3.22 & 0.09 \\
\hline Soil Temp $\left({ }^{\circ} \mathrm{C}\right)$ & $23.29 \pm 0.39$ & $23.59 \pm 0.63$ & $26.68 \pm 1.01$ & 27.63 & $0.0001^{* *}$ \\
\hline Bulk density $\left(\mathrm{g} \cdot \mathrm{cm}^{-3}\right)$ & $1.37 \pm 0.081$ & $1.47 \pm 0.053$ & $1.41 \pm 0.085$ & 5.27 & $0.05^{*}$ \\
\hline$\%$ SOC & $0.85 \pm 0.18$ & $0.62 \pm 0.1$ & $0.87 \pm$ & 3.28 & 0.091 \\
\hline SOC stock (total) & $117.12 \pm 7.99$ & $85.34 \pm 4.41$ & $121.87 \pm 3.51$ & 60.33 & 1.495 \\
\hline SOC stock (mean) & $11.70 \pm 0.79$ & $8.50 \pm 0.44$ & $12.20 \pm 0.35$ & 60.33 & 1.495 \\
\hline Clay (\%) & $29.57 \pm 2.22$ & $31.38 \pm 0.91$ & $26.81 \pm 1.25$ & 1.27 & 0.37 \\
\hline Silt (\%) & $27.51 \pm 1.01$ & $28.43 \pm 29.82$ & $27.11 \pm 1.16$ & 3.68 & 0.0904 \\
\hline Sand (\%) & $42.93 \pm 0.11$ & $40.19 \pm 0.66$ & $46.88 \pm 0.04$ & 342.2 & 3.37 \\
\hline
\end{tabular}

$\left(^{*}\right)$ - Significant difference between LULC types at $<0.05$ level; $\left({ }^{* *}\right)$-Significant difference between LULC types at $<0.001$ level. 


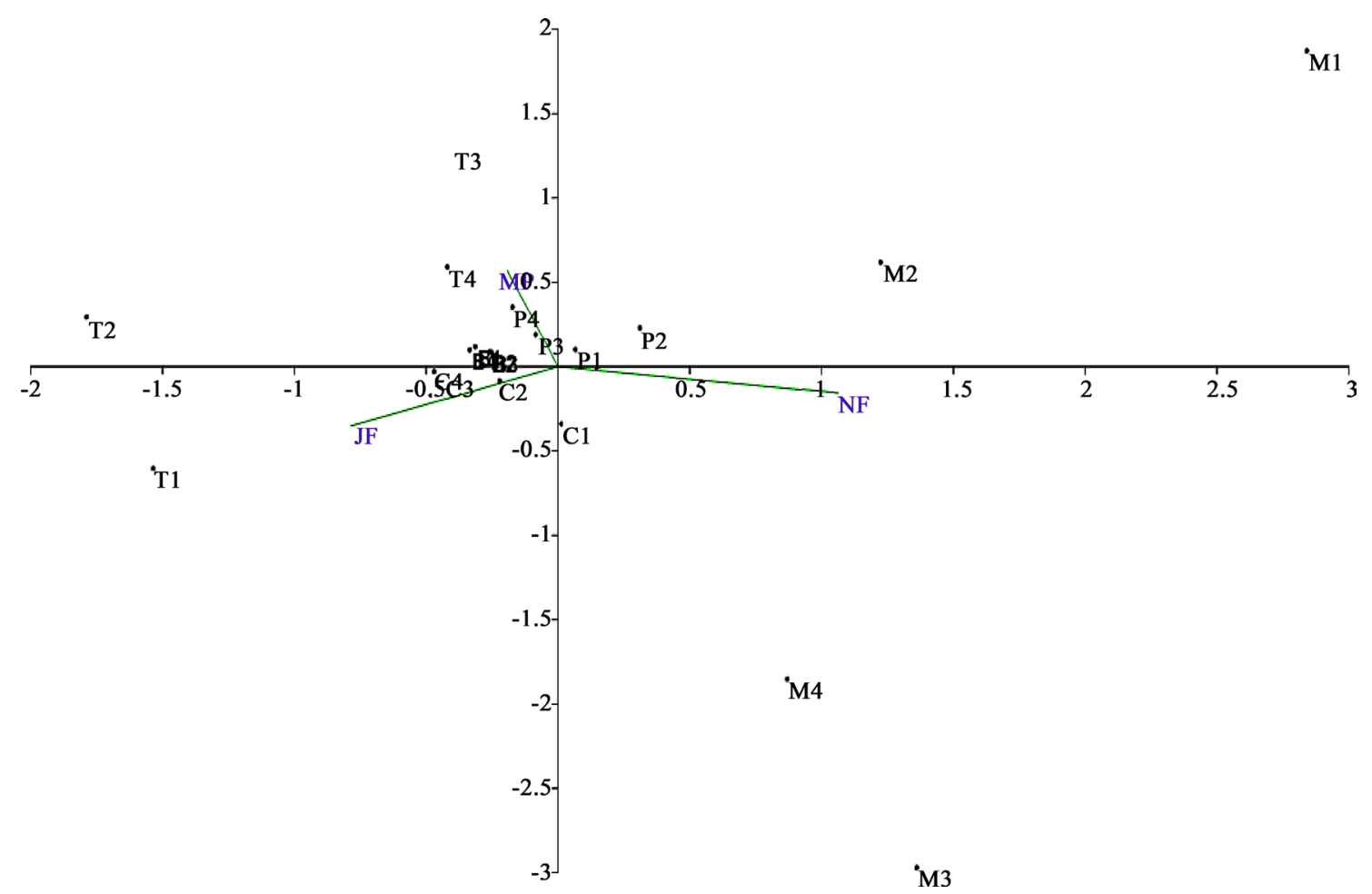

Figure 5. Principal Component Analysis (PCA) based on some soil edaphic factors (M-Moisture T-Temperature, $\mathrm{P}-\mathrm{pH}$, S-Soil organic carbon and BD—Bulk density) along different depth (1: 0 - $10 \mathrm{~cm}, 2: 10$ - $30 \mathrm{~cm}, 3: 30$ - $50 \mathrm{~cm}, 4: 50$ - 100 $\mathrm{cm}$ ) under three land use systems (NF-Natural Forest, MP-Manage Plantation and JF-Jhum Fallows) in Tripura, Northeast India.

(1.39) followed by JF (1.27) and NF (1.23). In top profile significant variations was found in bulk density among land use land cover classes $\left(\mathrm{F}_{2,12}=13.83 ; \mathrm{p}<0.001\right)$.

\subsection{Effect of Land Use on SOC}

While discussing the impact of land use and soil depth on SOC, we assumed that, perhaps in the beginning all land uses were NF and had similar value as we are estimating in NF. In all LULC, the value of SOC was less than $1.5 \%$ but more than $0.5 \%$. According to Greenland (1975) [32], 2\% of SOC as the minimum requirement for maintenance of satisfactory soil aggregates stability and above which no further increase in productivity achieve. The value reported in our study is comparable with the other neighbourhood studies. In tropical evergreen forest of neighbour state, 33.8 - $103.6 \mathrm{Mg} \mathrm{C} \mathrm{ha}^{-1} \mathrm{SOC}$ in top $1 \mathrm{~m}$ soil was reported from Mizoram [33]. In another study in Mizoram, SOC value was ranged between 82.1 - $134.1 \mathrm{Mg} \mathrm{C} \mathrm{ha}^{-1}$ [34]. From Assam [35], 115.9 $268.7 \mathrm{Mg} \mathrm{C} \mathrm{ha}^{-1}$ SOC was reported. However, SOC in the tropical moist deciduous forest of Mizoram was $147 \mathrm{Mg}$ $\mathrm{C} \cdot \mathrm{ha}^{-1}$ [34] and at another site it was reported $104.3 \mathrm{Mg} \mathrm{C} \mathrm{ha}^{-1}$ in top $1 \mathrm{~m}$ of soil [33]. In China [36], forest land use change at upper $40 \mathrm{~cm}$ soil profile led to $37.2 \%$ variability in SOC. Similar result was also reported from peninsular Spain [37], where land use change explains 33\% of SOC variability under different land uses and concluded that the SOC in secondary forest was higher than the plantations. Our results also suggest that the extent of land use resulted key impact on the distribution of SOC. Hence, SOC decrease with the increasing anthropogenic disturbance intensity (changes of LULC) and land management practices from NF to JF and NF to 25 year old monoculture i.e. Sal plantation. Similar kind of result was also reported from elsewhere [38] [39].

\subsection{Effect of Depth on SOC Stock}

The value of SOC decreases with depth, but $\mathrm{C}$ below a depth of $1 \mathrm{~m}$ has traditionally been regarded as inert and presumed to be unaffected by changes in land use [40]. In fact top $20 \mathrm{~cm}$ of soil, the C concentration was higher in the NF than plantations, which suggested that conversion of native forest and subsequent slashing and burning 


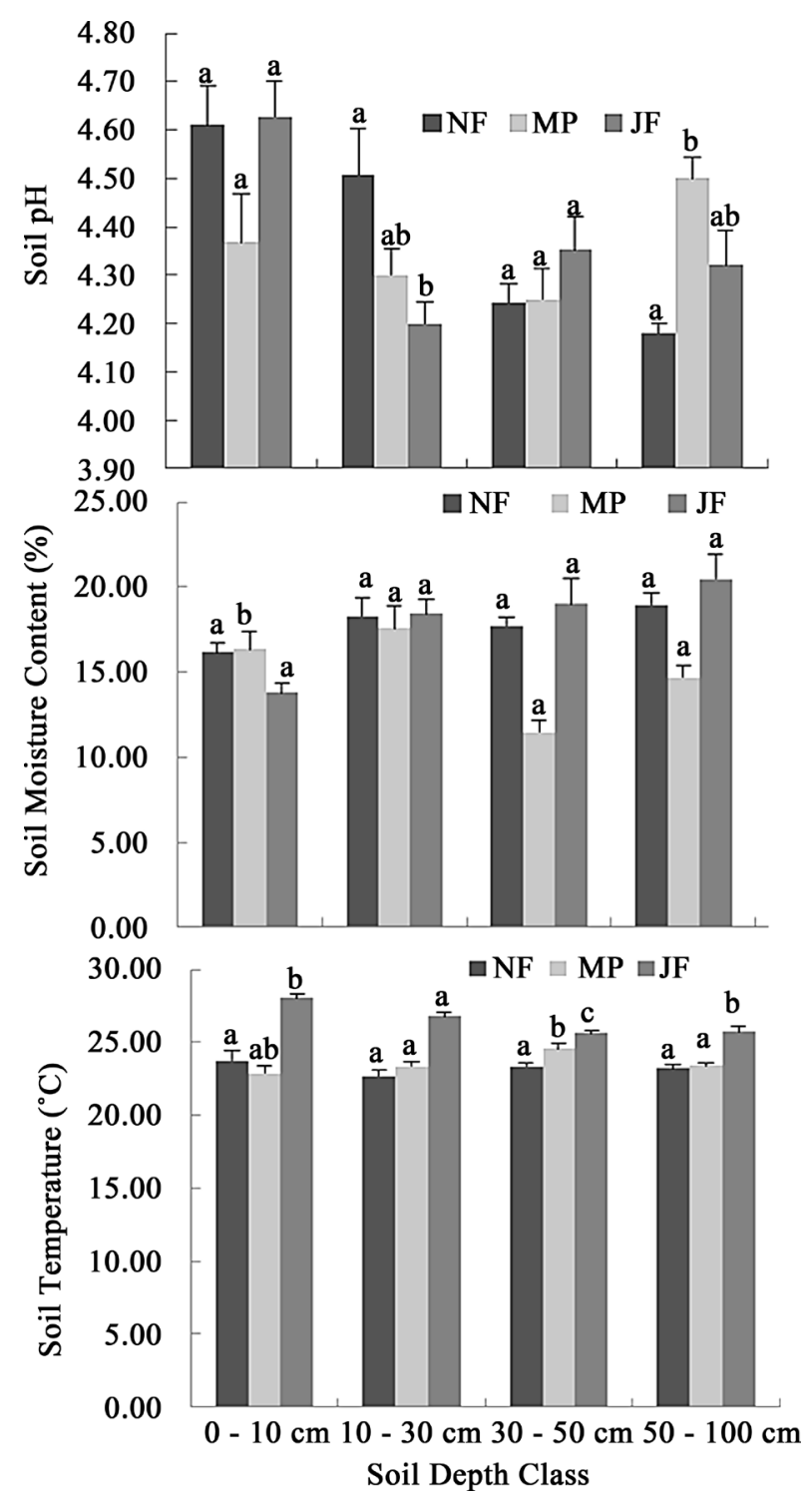

Figure 6. Value (Mean $\pm \mathrm{SE}$ ) of soil $\mathrm{pH}$, soil moisture content and soil temperature under three land use systems (NFNatural Forest, MP-Manage Plantation and JF-Jhum Fallows) in Tripura, Northeast India. Means sharing the same letter are not statistically different (Tukey, $\mathrm{p}<0.05$ ).

resulted some C loss from the topsoil. Similar results have been reported in other studies [20] [41]. Overall, the pools of $\mathrm{C}$ in whole soil in this study is in the range recorded from various forests, but was also found comparatively low than the ranges reported for tropical region at $0-100 \mathrm{~cm}$ soils depth $\left(130-160 \mathrm{Mg} \mathrm{C} \cdot \mathrm{ha}^{-1}\right)$ [42]. Present estimation of C \% is also comparable with other studies [28], where organic carbon varied from $0.54 \%$ in slashed and burnt sites to $1.55 \%$ in forested sites. The low C\% in the present study may due to slashing, burning and replanting; which caused significant reduction of soil organic matter, as observed by other earlier investigators [43] [44].

\subsection{Effect of Land Use and Soil Depth on Edaphic Properties}

PCA analysis suggested that Axis -1 showed maximum variation and eigen value due to different land use systems. Although, significant difference in edaphic factors along four soil depth gradients were also confirmed by PCA, where temperature, moisture, $\mathrm{pH}$ and SOC were mostly explained by PCA Axis. Although, Soil pH influences SOC by regulating microbial activities and higher $\mathrm{pH}$ value has a negative effect probably because of ac- 
celerated decomposition of soil organic matter (SOM) [45]. Soil texture has impacts SOM outputs through the role of clay in the protection of SOM from decomposition. It is well known that higher SOC are contained in finer soils and clay content has been recognized as a key factor controlling soil C dynamics [46]. Low organic matter in the soil also reduces the soil $\mathrm{pH}$ [47]. Continuous standing tree may lead to reduction in the soil $\mathrm{pH}$ as reported elsewhere [43]. In addition, the aids produced by the soil microorganisms and the acidic exudates from root of higher plants also influence the soil $\mathrm{pH}$ [1]. Because $\mathrm{pH}$ influences so many biological and chemical relationships simultaneously, soil $\mathrm{pH}$ in and of it provides little direct information as to which soil process is critically affected by it and in turn critically affects the productive capacity of a soil. In general, SOC increases with decreasing temperature, but trend is uncertain i.e. decrease in SOC with decreasing temperature has been reported in mountainous forested region of Western Oregon [46]. Heavy positive correlation between soil moisture and SOC reported elsewhere [38] [39]. In MP, the value of soil bulk density was highest may be due to the fact that the soil had least percentage of C. Many other studies have reported the inverse relationship between bulk density and Soil C [48] Acidic soils generally have less organic C i.e. inverse relationship between $\mathrm{pH}$ and organic $\mathrm{C}$ is being reported [48].

\section{Conclusion}

This study is pioneer in the approach of $C$ storage potentiality, especially in this part of north east India. The actual $\mathrm{C}$ regulation potential of these land uses can only be accessed by estimating the other pools of $\mathrm{C}$ and knowing the emission and sequestration patter of $\mathrm{C}$. The major outcome this study is that plantation establishment systems may lead to declines in ecosystem carbon pool compared to native forest. The amount of carbon was stored in the soil component indicating the need to implement soil management practices in the area to preserve the existing C stock. The three land uses systems can store $85.34 \mathrm{Mg} \mathrm{C} \cdot \mathrm{ha}^{-1}$ to $121.87 \mathrm{Mg} \mathrm{C} \cdot \mathrm{ha}^{-1}$ of C, which is low compare to other nearby area therefore, policy programs should promote the protection and establishment of NF. If plantation is encouraged it should be combined with the policy of increasing $C$ in soil. We should also rapidly maximize total $\mathrm{C}$ accumulation in the system. This may be done by using of modified silvicultural systems. Soil C estimations should provide important information for forest managers and policy makers on a regional scale and will also encourage adoption of restorative land uses and quantification of changes in the SOC pool over time, so that $\mathrm{C}$ credits can be traded in domestic and international markets.

\section{Acknowledgements}

We would like to thank Sri Samir Kumar Debnath, Sri Monthosh Roy and Jitaditya Debnath for their consistent supports during field survey. We are also thankful to Dr. A K Gupta, IFS, Principal Chief Conservator of Forest (PCCF), Tripura Forest Department, Govt. of Tripura for cooperation. Finally we are grateful to anonymous reviewer of this paper for critical evaluation and valuable suggestions.

\section{Conflict of Interest}

The authors declare none.

\section{References}

[1] Brady, N.C. and Weil, R.R. (2008) The Nature and Properties of Soils. Pearson Education, New Jersey, 975 p.

[2] Lambin, E.F., Turner, B.L., Geist, H.J., Agbola, S.B., Angelsen, A., Bruce, J.W., Coomes, O.T., Dirzo, R., et al. (2001) The Causes of Land Use and Land-Cover Change: Moving beyond the Myths. Global Environmental Change, 11, 261269. http://dx.doi.org/10.1016/S0959-3780(01)00007-3

[3] Darkoh, M.B.K. (2003) Regional Perspectives on Agriculture and Biodiversity in the Drylands of Africa. Journal of Arid Environments, 54, 261-279. http://dx.doi.org/10.1006/jare.2002.1089

[4] Bellamy, P.H., Lovelan, P.J.D., Bradley, R.I., Lark, R.M. and Kirk, G.J.D. (2005) Carbon Losses from All Soils across England and Wales. Nature, 437, 245-248. http://dx.doi.org/10.1038/nature04038

[5] IPCC (2000) Land Use, Land Use Change and Forestry. A Special Report of IPCC. Cambridge University Press, Cambridge, $377 \mathrm{p}$.

[6] Lal, R. (2004) Soil Carbon Sequestration to Mitigate Climate Change. Geoderma, 123, 1-22.

[7] Lal, R. (2004) Soil Carbon Sequestration Impacts on Global Climate Change and Food Security. Science, 304, 
1623-1627.

[8] Batjes, N.H. (1996) Total Carbon and Nitrogen in the Soils of the World. European Journal of Soil Science, 47, 151-163. http://dx.doi.org/10.1111/j.1365-2389.1996.tb01386.x

[9] Eswaran, H., Berg, E. and van den Reich, P. (1993) Organic Carbon in Soils of the World. Soil Science Society of America Journal, 57, 192-194. http://dx.doi.org/10.2136/sssaj1993.03615995005700010034x

[10] Lal, R.J., Kimble, J.M., Follett, R. and Stewart, B.A. (1998) Soil Processes and the Carbon Cycle. CRC Press, Boca Raton.

[11] Houghton, R.A. (2003) Revised Estimates of Annual Net Flux of Carbon to the Atmosphere from Changes in Land Use and Land Management 1850-2000. Tellus, 55B, 378-390.

[12] Verburg, P.H. and Neumann, K. and Nol, L. (2011) Challenges in Using Land Use and Land Cover Data for Global Change Studies. Global Change Biology, 17, 974-989. http://dx.doi.org/10.1111/j.1365-2486.2010.02307.x

[13] Houghton, R.A. (1995) Changes in the Storage of Terrestrial Carbon since 1850. In: Lal, R., Kimble, J., Levine, E. and Stewart, B.A., Eds., Soils and Global Change, Lewis Publishers, Boca Raton.

[14] Houghton, R.A. (2005) Aboveground Forest Biomass and the Global Carbon Balance. Global Change Biology, 11, 945-958. http://dx.doi.org/10.1111/j.1365-2486.2005.00955.x

[15] Li, L.H. (1998) Effects of Land-Use Change on Soil Carbon Storage in Grassland Ecosystems. Acta Phytoecol Sin, 22, 300-302. (In Chinese)

[16] Dixon, R., Brown, K.R.A., Houghton, R.A., Solomon, A.M., Trexler, M.C. and Wisniewski, J. (1994) Carbon Pools and Flux of Global Forest Ecosystems. Science, 263, 185-190. http://dx.doi.org/10.1126/science.263.5144.185

[17] Six, J., Conant, R.T., Paul, E.A. and Paustian, K. (2002) Stabilization Mechanisms of Soil Organic Matter: Implications for C-Saturation of Soils. Plant and Soil, 241, 155-176. http://dx.doi.org/10.1023/A:1016125726789

[18] Sampson, R.N. and Scholes, R.J. (2000) Additional Human-Induced Activities-Article 3.4. In: Watson, R.T., et al., Eds., Land Use, Land-Use Change, and Forestry, Published for the Intergovernmental Panel on Climate Change by Cambridge University Press, Cambridge, 183-281.

[19] FAO (2011) The Ex Ante Carbon Balance Tool. http://www.fao.org/tc/exact/en

[20] Guo, L.B. and Gifford, R.M. (2002) Soil Carbon Stocks and Land Use Change-A Meta Analysis. Global Change Biology, 8, 345-360. http://dx.doi.org/10.1046/j.1354-1013.2002.00486.x

[21] Van der Werf, G.R., et al. (2009) $\mathrm{CO}_{2}$ Emissions from Forest Loss. Nature Geoscience, 2, 737-738. http://dx.doi.org/10.1038/ngeo671

[22] Bai, Z.G., Dent, D.L., Olsson, L. and Schaepman, M.E. (2008) Proxy Global Assessment of Land Degradation. Soil Use and Management, 24, 223-234. http://dx.doi.org/10.1111/j.1475-2743.2008.00169.x

[23] Falloon, P., Jones, C.D., Ades, M. and Paul, K. (2011) Direct Soil Moisture Controls of Future Global Soil Carbon Changes: An Important Source of Uncertainty. Global Biogeochemical Cycles, 25, GB3010. http://dx.doi.org/10.1029/2010GB003938

[24] Sharma, S.P., Singh, M.V., Subehia, S.K., Jain, P.K., Kaushal, V. and Verma, T.S. (2005) Long Term Effect of Chemical Fertilizer, Manure and Lime Application on the Changes in Soil Quality, Crop Productivity and Sustainability of Maize-Wheat System in Alfisol of North Himalaya. AICRP on Long Term Fertilizer Experiments, IISS, Bhopal (MP) and Department of Soils, CSK HPKV, Palampur, HP. Research Bulletin, No. 2, 1-88.

[25] Forest Survey of India (2011) Annual Report. Ministry of Environment and Forests, Dehradun, India.

[26] SFR (2013) State Forest Report. Tripura Forest Department, Goverment of Tripura.

[27] Gupta, A.K. (2000) Shifting Cultivation and Conservation of Biological Diversity in Tripura, Northeast India. Human Ecology, 28, 605-629. http://dx.doi.org/10.1023/A:1026491831856

[28] Walkley, A. and Black, A. (1934) An Examination of the Degjareff Method for Determining Soil Organic Matter and a Proposed Modification of Chromic Acid Titration Method. Soil Science, 37, 29-38. http://dx.doi.org/10.1097/00010694-193401000-00003

[29] Blake, G.R. and Hartage, K.H. (1986) Bulk Density. In: Klute, A., Ed., Agronomy Society of America and Soil Science Society of America, Madison, 363-376.

[30] Anderson, J.M. and Ingram, J.S.I. (1989) Tropical Soil Biology and Fertility: A Handbook of Methods. CAB International, Wallingford.

[31] Hammer, O., Harper, D.A.T. and Ryan, P.D. (2001) PAST: Paleontological Statistics Software Package for Education and Data Analysis, Version 2.03. Palaeontologia Electronica, 4, 9 p. http://folk.uio.no/ohammer/past

[32] Greenland, D.J., Rimmer, D. and Payne, D. (1975) Determination of the Structural Stability Class of English and Welsh Soils, Using a Water Coherence Test. Journal of Soil Science, 26, 294-303. 
http://dx.doi.org/10.1111/j.1365-2389.1975.tb01953.x

[33] Singh, O.P. and Datta, B. (1988) Characteristics of Some Hill Soils of Mizoram in Relation to Altitude. Journal of Indian Soil Science, 31, 657-661.

[34] Singh, O.P., Datta, B. and Rao, C.N. (1991) Pedochemical Characterization and Genesis of Soils in Relation to Altitude in Mizoram. Journal of the Indian Society of Soil Science, 39, 739-750.

[35] Singh, J., Borah, I.P. and Boruah, A. (1995) Soil Characteristics under Three Different Plant Communities of Northeast India. Indian Forester, 121, 1130-1134.

[36] Wang, S., Wang, X. and Ouyang, Z. (2012) Effects of Land Use, Climate, Topography and Soil Properties on Regional Soil Organic Carbon and Total Nitrogen in the Upstream Watershed of Miyun Reservoir, North China. Journal of Environmental Sciences, 24, 387-395. http://dx.doi.org/10.1016/S1001-0742(11)60789-4

[37] Hontoria, C., Rodriguez-Murillo, J.C. and Saa, A. (1999) Relationships between Soil Organic Carbon and Site Characteristics in Peninsular Spain. Soil Science Society of America Journal, 63, 614-621. http://dx.doi.org/10.2136/sssaj1999.03615995006300030026x

[38] Paustian, K., Collins, H.P. and Paul, E.A. (1997) Management Controls on Soil Carbon. In: Paul, E.A., Paustian, K., Elliott, E.T. and Cole, C.V., Eds., Soil Organic Matter in Temperate Agroecosystems Long-Term Experiments in North America, CRC Press, New York, 15-49.

[39] Zeidler, J., Hanrahan, S. and Scholes, M. (2002) Land-Use Intensity Affects Range Condition in Arid to Semiarid Namibia. Journal of Arid Environments, 52, 389-403. http://dx.doi.org/10.1006/jare.2002.0990

[40] Fearside, P.M. and Barbosa, R.I. (1998) Soil Carbon Changes from Conversion of Forest to Pasture in Brazilian Amazonia. Forest Ecology and Management, 108, 147-166. http://dx.doi.org/10.1016/S0378-1127(98)00222-9

[41] Turner, J. and Lambert, M. (2000) Change in Organic Carbon in Forest Plantation Soils in Eastern Australia. Forest Ecology and Management, 133, 231-247. http://dx.doi.org/10.1016/S0378-1127(99)00236-4

[42] Jobággy, E.G. and Jackson, R.B. (2000) The Vertical Distribution of Soil Organic Carbon and Its Relation to Climate and Vegetation. Ecological Applications, 10, 423-436. http://dx.doi.org/10.1890/1051-0761(2000)010[0423:TVDOSO]2.0.CO;2

[43] Hölscher, D., Ludwig, B., Moller, R.F. and Fölster, H. (1997) Dynamic of Soil Chemical Parameters in Shifting Agriculture in the Eastern Amazon. Agriculture, Ecosystems \& Environment, 66, 153-163. http://dx.doi.org/10.1016/S0167-8809(97)00077-7

[44] Brand, J. and Pfund, J.L. (1998) Site and Watershed-Level Assessment of Nutrient Dynamics under Shifting Cultivation in Eastern Madagascar. Agriculture, Ecosystems \& Environment, 71, 169-183. http://dx.doi.org/10.1016/S0167-8809(98)00139-X

[45] Motavalli, P.P., Palm, C.A., Elliott, E.T., Frey, S.D. and Smithson, P.C. (1995) Nitrogen Mineralization in Humid Tropical Forest Soils: Mineralogy, Texture, and Measured Nitrogen Fractions. Soil Science Society of America Journal, 59, 1168-1175. http://dx.doi.org/10.2136/sssaj1995.03615995005900040032x

[46] Homann, P.S. (2007) Relations of Mineral-Soil C and N to Climate and Texture: Regional Differences within the Conterminous USA. Biogeochemistry, 85, 303-316. http://dx.doi.org/10.1007/s10533-007-9139-6

[47] Kataki, P.K. (Ed.) (2001) Rice Wheat Cropping System of South Asia: Efficient Production Management. Howorth Press New York, 317. http://dx.doi.org/10.1300/j144v03n02_01

[48] Homann, P.S., Harmon, M., Remillard, S. and Smithwick, E.A.H. (2005) What the Soil Reveals: Potential Total Ecosystem C Stores of the Pacific Northwest Region, USA. Forest Ecology and Management, 220, 270-283. http://dx.doi.org/10.1016/j.foreco.2005.08.035 


\section{Submit or recommend next manuscript to SCIRP and we will provide best service for you:}

Accepting pre-submission inquiries through Email, Facebook, LinkedIn, Twitter, etc.

A wide selection of journals (inclusive of 9 subjects, more than 200 journals)

Providing 24-hour high-quality service

User-friendly online submission system

Fair and swift peer-review system

Efficient typesetting and proofreading procedure

Display of the result of downloads and visits, as well as the number of cited articles

Maximum dissemination of your research work

Submit your manuscript at: http://papersubmission.scirp.org/ 